\title{
Public sector financial management and output growth in Nigeria: A predictive causality test and two-stage least square approach
}

\author{
Ernest Simeon Odiora Raymond Osi Alenoghena ${ }^{a^{*}}$ \\ ${ }^{a}$ Department of Economics, Faculty of Social Sciences, University of Lagos, Akoka Lagos, Nigeria. \\ ${ }^{*}$ Corresponding author's email: raymondalen@hotmail.com
}

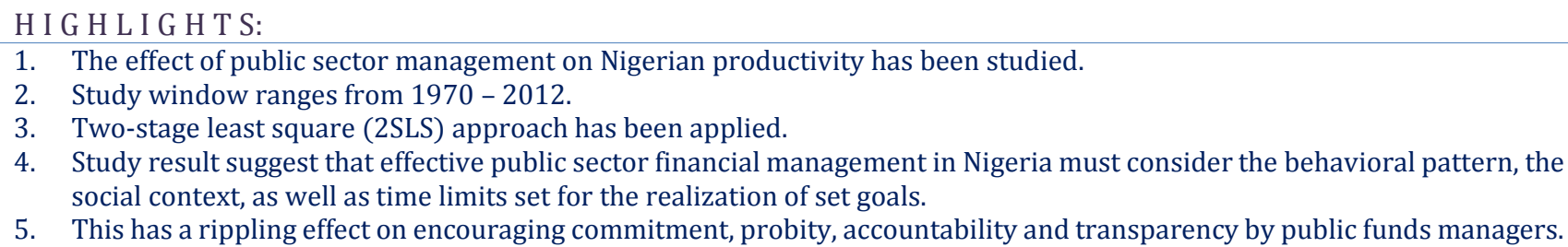

\begin{tabular}{ll} 
Article History & A B S T R A C T \\
\hline $\begin{array}{l}\text { Received: 20-01-2014 } \\
\text { Accepted: 24-02-2014 }\end{array}$ & $\begin{array}{l}\text { Our study empirically investigates the effect of public sector financial management on gross } \\
\text { production in Nigeria. The study starts with the review of some theoretical and empirical } \\
\text { literature as concerning the public financial management. After examining the stochastic } \\
\text { characteristics of each time series by testing their stationarity, the study used predictive } \\
\text { causality test, a two-stage least squares (2SLS) an instrumental variables approach for data }\end{array}$ \\
$\begin{array}{l}\text { Keywords: } \\
\text { set from 1970 to 2012. The findings were reinforced by the presence of static equilibrium } \\
\text { Outputity; }\end{array}$ & $\begin{array}{l}\text { relationship, as evidenced by the two-stage least squares. Results suggest that time limits set } \\
\text { for the realization of these goals would encourage commitment, probity, accountability and } \\
\text { Public sector financial } \\
\text { management; }\end{array}$ \\
transparency by public funds managers. Particular attention needs to be directed to the \\
management of these variables to reverse the current trend. The study therefore, concludes \\
that effective public sector financial management in Nigeria must consider the behavioral \\
pattern, the social context, as well as time limits set for the realization of set goals. This will \\
encourage commitment, probity, accountability and transparency by public funds managers.
\end{tabular}

JEL Classification:

D61; G14; H0.

DOI: http://dx.doi.org/10.18533/jefs.v2i01.45

(C) 2014 The Authors. This is an open access article under the terms of the Creative Commons Attribution License 4.0, which allows use, distribution and reproduction in any medium, provided the original work is properly cited.

\subsection{Introduction}

Public sector financial management is concerned with the economic behavior of government with regards to the methodologies, rules, regulations and policies that shape the planning, budgeting, forecasting, coordinating, directing, influencing and governing the inflow and outflow of funds in order to maximize the objective of the institution. In other words, public sector financial management (PSFM) deals with management of government spending, taxation borrowing, public debts, foreign reserves, foreign exchange system, level of liquidity in the economy and public finance auditing in order to achieve some stated objectives (Nwezeaku, 2010). Omopariola (2002) views government financial management as the branch of financial management concerned with the management of government 
operations - can be defined as the administration of the ways in which the government derives its financial resources, records, restricts and accounts for their use. In other words, it is the management of the inflows into and outflows of funds from the government treasury.

The public sector landscape is rapidly changing with an increasing emphasis on fiscal management and discipline, prioritization of expenditure and value for money. As a result, it is even more important that international donors, governments, national and local institutions, including regulators and professional accountancy bodies, work together in partnership to achieve long-lasting improvements, transparency and accountability in public financial management. Many countries in the developed and developing world have been making important and impressive achievements in strengthening public financial management and governance.

Recently, there is an increasing debate as to the effects or influence of the financial and productive activities of the government of Less Developed Economies (LDCs) on their economic growth and development. A key driver for the public financial management debate was the need to free the country from the status of least developed country (LDC) by 2020 . The government's strategy identified the direction of development and poverty reduction as well as stressing the importance of building public financial management at all levels to deliver better services for the poor. The objective of the program/debate was to promote a public financial management system to assure transparency and accountability through strengthening public financial management and capacity-building work forces (ACCA, 2010)

Focusing on the Nigerian, which is one of the most developed economies in Africa. The phenomenon of financial crisis, economic hardship and low productivity that has engulfed the country since the early 1980s, which has defied all solutions, crafted by the decisions and actions of financial managers of successive Nigeria governments has turned into a hydra-headed monster, so characteristic of a nightmare. For example, Nigeria's foreign exchange reserve crashed from 5.1 billion U. S. dollars in 1981 to 1.1 billion U. S. dollars in 1983. Consequently, government financial managers resorted to fiscal deficits, which unleashed the rapid increase in the inflation rate, which reached the unprecedented level of $72.3 \%$ in 1995 . The deficits were financed largely through fiduciary issue thus raising total domestic debt outstanding to N343.67 billion in 1996 (Olashore, 2001).

The petroleum industry provides $80 \%$ of foreign trade earnings and about $70 \%$ of budget revenues. For example, Nigeria's National budget has been increasing in geometric proportions over the years from N785.819bn in 2004 to N1.003trn in 2005 and from N1.3trn in 2006 toN1.6trn in 2007. Also from N2.1trn in 2008 and N3.1trn in 2009 (Nwezeaku, 2010), the budget had increased to N4.07trn and N4.9trn in 2010 and 2011 respectively, in just a matter of six years since the beginning of the current millennium. The economy of Nigeria have been bedeviled by sustained underdevelopment evidenced by poor human development indices including, poor income distribution, low life expectancy rate, poverty, unemployment, debt burden and poor standard of living in spite of governments' effort to mitigate it. For example, a recent World Bank report estimated that 80 percent of oil revenues in Nigeria benefits only 1 percent of the population (World Bank 2011). Before the debt forgiveness of 2006 the country was listed among the heavily indebted nations of the world with the external debt stock standing at a whopping \$37.5 billion (OkonjoIweala, 2006). Presently, Nigeria is still living with huge external debt burden which amounted to N1,026,903.92 Million in 2012(CBN, 2012)

However, in spite of the visible attempts by the various governments of Nigeria to manage their vast financial and other resources, there exists what has been referred to as "the paradox of plenty". Indeed, there has been rather a coexistence of abundant resources and wealth and extreme poverty in these economies unlike their developed counterparts. The country which ranked sixth in World oil output is ranked 156 out of 186 countries in human capital development (UNDP, 2011). About 60 per-cent of the population live in abject poverty. Well management of public sector fund has always been the tool available to any governments for the implementation of developmental goals and objectives. It is seen as being crucial to the growth and development of any economy. Ordinarily, management of the resources of any economy should lead to poverty reduction, improvement in the standard of living of its citizens, mitigation of inequalities in income distribution and improve the general wellbeing and productivity of the economy.

Public financial management is absolutely critical to improving the quality of public service outcomes. It affects how funding is used to address national and local priorities, the availability of resources for investment and the cost-effectiveness of public service. Most available works in this area have concentrated on the size of public expenditure and its determinants without giving much consideration to the effects of these public financial management activities on the level of output production. Against this background, the research question that necessitates and steer this study is; what is the magnitude of relationship between public sector financial management (as measure by fiscal instruments) and output productivity in Nigeria. The main objective of this study is to investigate the relationship between public sector financial management (PSFM) and economy productivity 
The study is organized into seven sections. Section one is the introduction, giving a general idea of the research. Section two centers on the literature review, both the theoretical and empirical literatures. Section three shows the theoretical framework of the public sector financial management and growth theories while section four is the method of data analysis and model specification. Section five is the estimation of model and interpretation of results. Section six and seven gives policy implication of findings and recommendations and conclusion of the study, respectively.

\subsection{Literature review: Public sector financial management and output growth}

In theory the relationship between government expenditures and economic growth is ambiguous. Long ago, in 1651, Thomas Hobbes described life without government as "nasty, brutish, and short" and argued that the law and order provided by government was a necessary component of civilized life. Taking the Hobbesian view, certain functions of government such as the protection of individuals and their property and the operation of a court system to resolve disputes should enhance economic growth. Viewed from another angle, secure property rights, enforcement of contracts and a stable monetary regime provide the foundation for the smooth operation of a market economy.

There exists a consensus in the literature that an adequate and effective public sector financial management is critical to any successful development process aimed at achieving high employment, sustainable economic growth, price stability, long viability of the balance of payments and external equilibrium. Fatile and Adejuwon (2010) explain the issues, lessons and future directions in public sector reform in Africa. According to them, public service has always been the tool available to African governments for the implementation of developmental goals and objectives. It is seen as being crucial to the growth and development of African economies. The paper reviews the nature of the current public sector reform in Africa, lessons of international and African perspectives, and the future directions of the public sector reform in Africa. They argued that the reform is in the interest of the conservative international financial institutions that were merely interested in globalizing the neo-liberal economy orthodoxy for the interest of powerful global capital and not in promoting autonomous development, which is what Africa need for economic progress. They therefore, concluded that effective public sector reform in Africa must put into consideration the behavioral pattern, the social context, as well as cultural milieu of the people whom the reform is meant for together with the vehicle of the reform.

Tchokote (2006) said fiscal and monetary policy instruments are the main instruments of achieving the macroeconomic targets. The basic fiscal policy measures are public expenditure and tax while the monetary police instruments include the devices of reserve requirements, discount rates and open market policy. Differing opinions have indeed continued to emerge on how fiscal policy measures (management of public finance) can affect economic activities. The genesis of these controversies has been traced to the theoretical exposition of the different schools of thought namely: the Classical; the Keynesian; and the neoclassical schools of thought.

This, therefore, suggests that the significance of stabilization policy (fiscal and monetary policies) cannot be overemphasized in any growth oriented economy. Growth and poverty alleviation have received attention in Nigeria (Obadan, 2004) and (Ogwumike and Ekpenyong, 2005).Furthermore, previous works on Nigeria have relied on partial frameworks. The differential effects of fiscal policy on various productive sectors and on the different income groups are neither explored nor captured. Most of these studies have preoccupied themselves with presenting poverty profiles in Nigeria. Some of them have attempted to examine the impact of growth on inequality. But it is quite clear from the literature that growth, inequality and poverty can influence, and in turn influenced by, fiscal policy.

Ezirimand Muoghalu (2006) investigated the extent to which factors like population growth, urbanization effects and taxation affect the size of public expenditure in less developed countries like Nigeria; and concluded that inflation constituted the most important factor that accounted for changes in government financial management. Offurum (2005) in an extensive study investigated the impact of public expenditure on economic growth. He made a comparative analysis of selected countries and concluded that significant relationship exists between some macroeconomic variables and changes in public expenditure.

According to Olaniyan (2000), under ideal and perfectly competitive situations, economic policies for growth or stabilization should be employed in such a way as to equate the marginal productivity of government investment to that of private investment. This has to be so because the equilibrium situation in national income determination implies that resource employed in government investment activities should be as productive as in any alternative employment. The implication of government investment should be equal to the gross rate of interest at which the private investment is undertaken

According to Oji (2008), public sector financial management in the less developed economies involves the process of utilizing the scarce resources of the state in a manner that will achieve reduction in poverty. These reforms built on theories of public choice (Buchanan, 1986), and principal-agent (Eisenhardt 1989), along with initiatives first 
adopted in the private sector such as "total quality management" and "managing for results" (Drucker, 2001), exhortations like "What gets measured, gets done" and adaptations to the public sector including "new public management" and related formulations (Moynihan and Ingraham, 2003 and Foltin, 2005).

Wildavsky (1986) takes a pragmatic approach, arguing that traditional budgeting forms (incremental, line items, annual budget) persist because their defects are also virtues. For example, incremental budgeting is easier because it isn't comprehensive, and because it estimates future revenue and spending based on past performance, which can be known, rather than on the future prospects, which are unknown.

In contrast, Campos and Pradhan (1996) set out three ideal outcomes of a public expenditure management system: fiscal discipline, allocation of resources consistent with policy priorities, and good operational management. Fiscal discipline means expenditure control and careful management of deficits. It's a challenge even for developed countries to achieve, because of a number of "tragedies of the commons", such as politicians focused on staying in power by keeping stakeholders content, and often tempted to finance spending through deficits, which are paid back by future generations. This challenge is greater in developing countries where political support of politicians and top officials is often gained through providing patronage. In addition to deficit spending, some countries show lack of fiscal discipline by using windfalls from high resource prices such as oil to finance consumption, rather than to invest in productive assets for future generations.

The IMF (2010) in its Regional Economic Outlook on Sub-Sahara African countries found that countries with stronger budget institutions tend to have lower fiscal risks and that countries with lower fiscal risks tend to grow faster. Although causality may go in both directions, fiscal risks are positively correlated with real output growth volatility and negatively correlated with real output growth.

In a very recent work on Nigeria by Stevens and Freinkman (2008) on "Stocktaking the Reforms in Public Financial Management", the authors employed the Global Standards and the Public Expenditure and Financial Accountability (PEFA) framework to assess Public Sector Financial Management performance in Nigeria from 1999 to 2007. PEFA is a product of a collective effort by EU, IMF and World Bank to develop an integrated framework which contains 28 high level Performance Indicators, each with graduations to benchmark countries and the performance of their governments in public financial management. The study found that the PEFA diagnostics revealed a trend towards a system-wide upgrade in Nigeria's Public Sector Financial Management (PFM) system.

Ezirim and Muoghalu (2006) investigated the extent to which factors like population growth, urbanization effects and taxation affect the size of public expenditure in less developed countries like Nigeria; and concluded that inflation constituted the most important factor that accounted for changes in government financial management. Also, Offurum (2005) in an extensive study investigated the impact of public expenditure on economic growth. He made a comparative analysis of selected countries and concluded that significant relationship exists between some macroeconomic variables and changes in public expenditure. However most of these works have concentrated on the size of public expenditure and its determinants without giving much consideration to the effects of these public financial management activities on the growth and development of the economies under study.

Ojo (2009) encourage local government administrators in Nigeria to borrow from their counterparts in the private sector who have always emphasized corporate growth and viability in their management styles. The financial resource of the local government should be efficiently managed for the general growth and development of the local government areas. However, a cursory examination of the structure of selected macroeconomic indicators of performance of fiscal policy revealed that the Nigerian situation has been far from ideal. Disheartening, however, is the fact that budget deficits in Nigeria hardly comply with these principles. The unproductive performance of ever increasing government expenditure is also reflected in the level of economic growth proxied by real GDP growth rate which was, in fact, negative between 1981 and 1985 and 1987 and suggested an average of 2.6 percent over the period under consideration (1981-2004). Also, the high degree of instability became more obvious with the inflationary trends maintaining two digits for seventeen (17) years out of the twenty five years of study coverage. By and large, the behavior of fiscal policy in Nigeria has followed unsteady pattern, assessing the significance of the policy; therefore, in the actualization of sustainable economic growth is imperative more so that the country is working towards achieving the millennium development goals.

Nwezeaku (2010) investigate the relationship between public sector financial management and economic development with special reference to Nigeria and Ghana. The study used the ordinary least squares procedure against annual data from 1980 through 2006 for the countries. These were employed to evaluate the general impact on the economies while the log-log model was employed to examine the incremental growth of the economies. Also, he made of the Gini index theory as a measure of the degree of inequality of income distribution. From his model the global statistics indicate overall high explanatory powers of the model while, the relative statistical results indicate a highly significant causality between public sector financial management and persistent economic underdevelopment. 
His result showed that Management of inflation, government revenue, government expenditure and investment appear to have the greatest negative effects on the efforts of these governments especially that of Nigeria. He recommended that sub-Saharan African economies should pay particular attention to the management of these variables to reverse the trend.

\subsection{Theoretical framework: Public sector financial management and growth theories}

Theories have been put forward in an attempt to explain the use of scarce resources. Evidently these theories suggest that economic development is a product of prudent management of a society's scarce resources. This has also led to theories of growth in public expenditure which is a major component of public sector financial management. Some of these theories include:

Rostowin (1960) put forward the Rostowstage theory, this theory posits that it is possible to classify societies into five categories based on their level of economic development namely the traditional society, the per- conditions for take-off, the take-off into self-sustaining growth, the drive to maturity and the age of high mass consumption. Here economic growth and development is assumed to be affected by policy formulation, policy planning, budgeting, fiscal discipline and institutional reforms all of which must be an integral part of public sector financial management.

Rostow emphasized the influence of stages of economic development in the size of public expenditure and public sector financial management. According to him, lower levels of economic development require higher levels of investments in other to create necessary infrastructure for gainful economic breakthrough. As such economies approach maturity in economic development, much of the increases in public expenditure would be prompted by repeated market failure. A fuller discussion of these theories can be found in Onuchukwu (2001) and Offurum (2005).

Moreover in 1960, Rastow emphasized the influence of stages of economic development in the size of public expenditure and public sector financial management. According to him, lower levels of economic development require higher levels of investments in other to create necessary infrastructure for gainful economic breakthrough. As such economies approach maturity in economic development, much of the increases in public expenditure would be prompted by repeated market failure.

Musgrave posits that changes in the income elasticity of demand for public services exist at three stages of percapita income of the citizenry. At a low level of per-capita income (typical of preindustrial societies in developing economies), demand for public services tend to be generally very low because nearly all incomes are devoted to satisfaction of primary needs. At this state, public expenditure is also at a low level, when per-capita income starts rising, a demand for public services supplied by the public sector such as health, education and transport services starts rising which engenders the need for government to increase expenditure on them. The last stage is at the higher levels of per-capita income typical of advanced economies. Here the rate of public sector growth tends to fall as the more basic needs are satisfied (Onuchukwu, 2000; Offurum, 2005).

Ricardo (1783) in the theory of differences argued on the predicated on the belief that if the receipts of the government (production) are comparatively greater than aggregate spending (consumption), the standard of living of the society will improve and there will be steady growth of Gross Domestic Product (GDP) and a sustainable per-capita income which culminates in economic growth and development.

Smith (1923) introduce the progressive state theory, he asserted that the progressive state is one which is in reality the cheerful and hearty state to all the different orders (groups) of the society or country. Smith saw prudent management of public finance as a progressive state of maintaining high standard of living for people and high per capita income over time. Perhaps the greatest problem of these theories and models is that they seem to describe and explain observed situations, they do not have or provide insight or explanations as to the causal factors. All of them recognize the existence of changes in levels of economic development but fail to explain what caused the changes. Of course, it would be unrealistic to assume natural factors since such assumptions would not explain why country $\mathrm{A}$ is growing and country $\mathrm{B}$ is not, and country $\mathrm{C}$ is even retarding. Even if we assume a combination of natural factors and efficiency in public sector financial management, the controversy as to which theory or model suits which natural environment comes into force. A fuller discussion of these theories can be found in Onuchukwu (2001) and Offurum (2005).

\subsection{Data analysis and model specification}

To achieve our research objectives and analyze the marginal impact public sector financial management on the productivity of output, it is necessary to choose a proper functional form for the econometric model. Our estimation technique consists of three steps procedures. The first step is the unit root test which involves the determination of 
the order of integration, using the Im, Pesaran and Shin W-stat test. The second step is run the predictive causality test in order to select the instrumental variable to be included in the model. The third step is to estimate the model using the two-stage least squares (2SLS) regression method which is run over the sample period 1970-2012. These tests are to enable us give a good explanation regarding the relationship that exist between the dependent variables and independent variables, namely;

a. Gross Domestic Product is proxy for Output Growth(OUTPG)

b. Domestic Debt (DODEBT)

c. External Debt (EXDEBT)

d. Total Government Collected Revenue (oil revenue and non- oil revenue) (GOVREV)

e. Government total capital and recurrent expenditure on Administration (general administration, defense, internal security and national assembly) (GTEAD)

f. Government total capital and recurrent expenditure on Economic Services (agriculture, construction, manufacturing, transport \& communication and other economic services) (GTEES)

g. Government total capital and recurrent expenditure on Social and Community Services (education, health and other social and community services) (GTESC)

h. Government total capital and recurrent expenditure on Transfers (public debt servicing, pensions and gratuities, contingencies/subventions and other/other CFR charges) (GTTRA)

i. Changes in government overtime (Military $=0$ and Civilian $=1)$ is represented by a dummy variable (CGOV)

In this study, output productivity is depending on other defined variables. The data set for this paper consists of annual time series from 1970 - 2012 and they were obtained from Central Bank of Nigeria Statistical Bulletin (CBN, 2011, 2012).We employ a predictive causality test and a two-stage Least Squares regression (2SLS) methods to analysis the collected data.

\subsection{The choice of the techniques}

We carry out the predictive causality tests and test whether an endogenous variable can be treated as exogenous. This enables us to make selection for a set of variables to be included on the instrumental variable (IV) list. For this example, we cannot reject the hypothesis that OUTPG does not Granger cause DODEBT and we cannot also reject the hypothesis that DODEBT does not Granger cause OUTPG. Therefore it appears that Granger causality runs two-way from DODEBT to OUTPG and not one-way. If causality is unidirectional an endogenous variable cannot be treated as exogenous vice versa. But if causality is bilateral, is suggested when the sets of DODEBT and OUTPG coefficients are not statistically significantly different from zero in both (see Appendix 2). This is a two-way relationship; therefore, an endogenous variable can be treated as exogenous. We however believe that all government functionaries (variables) in our model are exogenous and uncorrelated with the disturbances $(u)$, to be used as instruments.

Two-stage least squares (2SLS) is a special case of instrumental variables regression. The basic idea behind 2SLS is to replace the (stochastic) endogenous explanatory variable by a linear combination of the predetermined variables in the model and use this combination as the explanatory variable in lieu of the original endogenous variable. The 2SLS method thus resembles the instrumental variable methodof estimation in that the linear combination of the predetermined variables serves as an instrument, or proxy, for the endogenous regressor.

A fundamental assumption of regression analysis is that the right-hand side variables are uncorrelated with the disturbance term. If this assumption is violated, both OLS and weighted LS are biased and inconsistent. There are a number of situations where some of the right-hand side variables are correlated with disturbances. Some classic examples occur when, there are endogenously determined variables on the right-hand side of the equation and righthand side variables are measured with error. For simplicity, we will refer to variables that are correlated with the residuals as endogenous, and variables that are not correlated with the residuals as exogenous or predetermined. The standard approach in cases where right-hand side variables are correlated with the residuals is to estimate the equation using instrumental variables regression.

The idea behind instrumental variables is to find a set of variables, termed instruments, which are, both (1) correlated with the explanatory variables in the equation, and (2) uncorrelated with the disturbances. These instruments are used to eliminate the correlation between right-hand side variables and the disturbances. There is no separate stage in 2SLS both stages are estimated simultaneously using instrumental variables techniques (Gujarati and Sangeetha, 2007).

\subsection{Specification of the model}

More formally, let $\mathrm{Z}$ be the matrix of instruments, and let $\mathrm{y}$ and $\mathrm{X}$ be the dependent and explanatory variables. In matrix notation, the coefficients computed in 2SLSgeneral form are given by,

$$
\alpha_{T S L S}=\left(X^{\prime} Z\left(Z^{\prime} Z\right)^{-1} Z^{\prime} X\right)^{-1} X Z\left(Z^{\prime} Z\right)^{-1} Z^{\prime} y
$$


and the estimated covariance matrix of these coefficients is given by:

$$
\hat{\Sigma}_{T S L S}=s^{2}\left(X^{\prime} Z\left(Z^{\prime} Z\right)^{-1} Z^{\prime} X\right)^{-1},
$$

Where, $s^{2}$ is the estimated residual variance (square of the standard error of the regression)

Our instrumental variables general form equation is given by;

Let the equation of interest be

$$
y_{i}=x_{i}^{\prime} \alpha+u_{i}
$$

Where, $x_{i}$ is $k \times 1$ and assume that $\mathrm{E}\left(x_{i} u_{i}\right) \neq 0$ so there is endogeneity. We call (03) the structural equation. In matrix notation, this can be written as

$$
y=x \alpha+u
$$

The $\ell \times 1$ random vector $z_{i}$ is an instrumental variable for (3) if $\mathrm{E}\left(z_{i} u_{i}\right)=0$ :

In a typical set-up, some regressors in $x_{i}$ will be uncorrelated with $u_{i}$ (for example, at least the intercept). Thus we make the partition

$$
x_{i}=\left(\begin{array}{l}
x_{1 i} \\
x_{2 i}
\end{array}\right) k_{1}
$$

Where $\mathrm{E}\left(x_{1 i} u_{i}\right)=0$ yet $\mathrm{E}\left(x_{2 i} u_{i}\right) \neq 0$ : We call $x_{1 i}$ exogenous and $x_{2 i}$ endogenous. By the above definition, $x_{1 i}$ is an instrumental variable for (3); so should be included in $z_{i}$ : So we have the partition

$$
z_{i}=\left(\begin{array}{l}
x_{1 i} \\
z_{2 i}
\end{array}\right) \begin{aligned}
& k_{1} \\
& \ell_{2}
\end{aligned}
$$

Where $x_{1 i}=z_{1 i}$ are the included exogenous variables, and $z_{2 i}$ are the excluded exogenous variables. That is $z_{2 i}$ are variables which could be included in the equation for $y_{i}$ (in the sense that they are uncorrelated with $u_{i}$ ) yet can be excluded, as they would have true zero coefficients in the equation. The model is just-identified if $\ell=k$ (i.e., if $\ell_{2}=k_{2}$ ) and over-identified if $\ell>k$ (i.e., if $\ell_{2}>k_{2}$ ):We have noted that any solution to the problem of endogeneity requires instruments. This does not mean that valid instruments actually exist (Hansen, 2009)

In this study we are interested in estimating the log of an output growth equation relating output growth (LOUTPG) to the log of domestic debt (LDODEBT), the log of external debt (LEXDEBT),the log total government collected revenue (LGOVREV), the log of administration (LGTEAD), the log of government total expenditure on economic services (LGTEES), the log of government total expenditure on social and community services (LGTESC), the log government total expenditure on transfers (LGTTRA)and a constant $(\alpha)$.

From the established predictive causality carried out in Appendix 2 we believe that all the explanatory variables LDOMDEBT and LEXDEBT are endogenous and therefore correlated with the residuals. However, we believe that lagged output growth (LOUTPG(-1),LGOVREV, LGTEAD, LGTEES, LGTESC, LGTTRA, changes in the type of government overtime (military rule $=0$ and civilian rule $=1$ ) (CGOV) and a constant $(\alpha)$ are exogenous and uncorrelated with the disturbances, so that these variables are used as instruments.

In order to examine the relationship between the dependent and independent variable, we take linear approximation of the functional form of the model and add error term $(\mu)$. To generate coefficients that would explain elasticities between the dependent variable and the independent variables, we take natural logarithm of the variables. Hence, we run a double-log model with an additive error term. This yields an econometric equation. Therefore, our equation specification in it empirical form is then,

$$
\begin{aligned}
\sum \text { LOUTPG }_{t}= & \alpha_{0}+\alpha_{1} \sum L D O D E B T_{t}+\alpha_{2} \sum L E X D E B T_{t}+\alpha_{3} \sum L G O V R E V_{t}+ \\
& \alpha_{4} \sum L G T E A D_{t}+\alpha_{5} \sum L G T E E S_{t}+\alpha_{6} \sum L G T E S C_{t}+\alpha_{7} \sum L G T T R A_{t}+u_{t}
\end{aligned}
$$

and our instrument list are:

$$
\begin{aligned}
\underbrace{}_{\text {inst }} & \alpha \sum \text { LOUTPG }_{t-1} \sum \text { LGOVREV }_{t} \sum \text { LGTEAD }_{t} \sum \text { LGTEES }_{t} \quad \sum \text { LGTESC }_{\mathrm{t}} \sum \text { LGTTRA }_{\mathrm{t}} \\
& \sum \mathrm{CGOV}_{\mathrm{t}}
\end{aligned}
$$


The a-priori assumptions for the above model based on (equation 7) are: $\alpha_{0}>0, \alpha_{1}>0, \alpha_{2}<0, \alpha_{3}>0, \alpha_{4}>0$, $\alpha_{5}>0, \alpha_{6}>0, \alpha_{7}<0 . \alpha_{\text {s }}>0$ implies a positive relationship between the endogenous variable and exogenous variables, that is, an increase in these exogenous variables will lead to an increase in output growth overtime while, $\alpha_{s s}<0$ implies negative relationship, that is an increase in these exogenous variables will lead to a decrease in output growth overtime. The expectations of the model are quite clear from the a priori signs of the coefficients based on economic literatures specifying the developing countries.

\subsection{Result and analysis}

\subsection{Result of series unit root test}

To avoid spurious results which may affect in determining the accuracy of the formulated model equation (7) which may due to non-stationarity of data series, we test for data stationarity and determine if all variables are integrated at the same order. This will reveal the exalt relationship between the endogenous variable and exogenous variables. In this study, to determine the order of integration, we test for the presence of unit root, Im, Pesaran and Shin Wstat test. The summary of the results are presented in Appendix 1.

The tested series result in Appendix 1 shows that there is an existence of unit root. This implies that all the series were not stationary at levels. With zero maximum lag and with the various probabilities values, the test statistics show that the variables are integrated at order of one. From the ADF test statistics and zero maximum lag the results show that D(LOUTPG), D(LDODEBT), D(LEXDEBT), D(LGOVREV), D(LGTEAD), D(LGTEES), D(LGTESC), D(LGTTRA) and $\mathrm{D}(\mathrm{CGOV})$ were all integrated at order one, that is I(1) or they were stationary at first difference. Comparing the variables levels with their first difference (the ADF unit root test statistic) and various probabilities, the test statistics show that the variables are integrated at order of one. All the variables were statistically significant at $1 \%, 5 \%$ and $10 \%$ critical values in first difference. This implies that all the series are non-stationary at levels except. Therefore the null hypothesis $(\rho=1)$ is accepted at levels and the null hypothesis $(\rho=1)$ that the series are non-stationary after the first and second difference is rejected for all the series. For the random walk above, there are unit roots, so it is an I(1) series. We therefore concluded that the series are of order one I(1).

\subsection{Analysis of the predictive causality tests result}

We present in Appendix 2 the results of the predictive causality of the $F$ test using 2 and 3 (annual) lags. In each case, the null hypothesis is that the explanatory variable does not 'Granger' cause output growth and vice versa.

These results suggest that the direction of causality is from domestic debt (LDODEBT) to output growth (LOUTPG) and also from external debt (LEXDEBT) to output growth (LOUTPG) since the estimated $F$ is significant at the 5 per cent level; the critical $F$ value is 2.18 (for 7 and $36 \mathrm{df}$ ). On the other hand, there is "reverse causation" from output growth (LOUTPG) to domestic debt (LDODEBT) and external debt (LEXDEBT), since the $F$ value is statistically significant. In order words both debts cause output growth and output growth cause both debts, a bilateral causality.

Results also suggest that the direction of causality is from all government functionaries (total government collected revenue (LGOVREV), administration (LGTEAD), government total expenditure on economic services (LGTEES), government total expenditure on social and community services (LGTESC), government total expenditure on transfers (LGTTRA)) and changes in the type of government (CGOV) to output growth (LOUTPG), since the estimated $F$ is significant at the 5 per cent level and statistically different from zero. On the other hand, there is no "reverse causation" from output growth to all government functionaries and changes in the type of government; since their $F$ values are statistically insignificant compared to the critical $F$ value of 2.18. In order words government functionaries cause output growth and output growth do not cause government functionaries, a unidirectional causality.

\subsection{Interpretation of the result of estimated models}

Equation (7) is estimated subject to the stationarity result which shows that the series were all integrated at order one I(1). The instrumental variables were chosen based on the outcome of the predictive causality test result. Therefore, the expected equation to be estimated is

$$
\begin{aligned}
& \mathrm{D}(\text { LOUTPG })={ }^{\alpha}+\alpha_{1} \mathrm{D}(\text { LDODEBT })+{ }^{\alpha_{2} \mathrm{D}(\text { LEXDEBT })}+{ }^{\alpha_{3} \mathrm{D}(\mathrm{LGOVREV})}+{ }^{\alpha_{4} \mathrm{D}(\mathrm{LGTEAD})}+{ }^{\alpha_{5} \mathrm{D}(\mathrm{LGTEES})}{ }^{\alpha_{6}}
\end{aligned}
$$

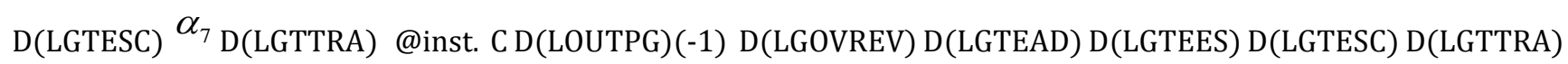

$$
\begin{aligned}
& \text { D(CGOV) }
\end{aligned}
$$


Substituted Coefficients:

$\mathrm{D}($ LOUTPG $)=1.33+0.70 \mathrm{D}($ LDODEBT $)-0.16 \mathrm{D}($ LEXDEBT $)+0.60 \mathrm{D}($ LGOVREV $)+$ $0.12 \mathrm{D}$ (LGTEES) $+0.003 \mathrm{D}($ LGTESC $)-0.32 \mathrm{D}$ (LGTTRA)

$0.32 \mathrm{D}(\mathrm{LGTEAD})-$

From the estimated outcome of the model, it is clear that the parameters are partially in line with our a priori expectation for the fact that some three of the eight parameters are inversely related to output growth as against the predicted two. Furthermore, an examination of the results shows a good fit in terms of the standard error of the parameters, which indicates a non-negative constant term for output growth (0.59) no matter the changes in the explanatory variables.

Looking at the impacts estimate of coefficients, it is clear that some of the explanatory variables in the model are more significant than the other. In equation (9) or Appendix 3, it is obvious that if domestic debt (DEDOBT), total government collected revenue (GOVREV), administration(GTEAD) and government total expenditure on social and community services (GTESC)increase let say, by one percent, output level will increase by 0.70 percent, 0.60 percent, 0.32percent and 0.003percent, respectively, and if external debt (EXDEBT), government total expenditure on economic services (GTEES), government total and government total expenditure on transfers (GTTRA)increase let say, by one percent, output level will decrease by 0.16 percent, 0.12 percent and $0.32 \%$, respectively, given their coefficients.

The coefficient in the results showed that domestic debt and total government collected revenue are the most important variables in determining output in Nigeria. It implies that their significance will be much felt. Still on the positive relationship, the result showed that government total expenditure on social and community services thought positively related contribute very little to output growth. This implies that the fund channeled to economic services sectors of the economy is not well managed to provide the adequate intended productivity. Our result shows that Government expenditure on social and community services (GTESC) makes the least impact on output productivity. This is because the Nigerian Government has not placed priority on this sector despite its utmost importance in determining the future direction and magnitude of the country's output productivity. Government expenditure on social and community services include the Country's expenditure on; education, health and other social and community services.

As against our a priori expectation, it is surprisingly that government total capital and recurrent expenditure on economic services (GTEES) which include; agriculture, construction, transport \& communication and other economic services displayed inverse relationship. It implies that the management of the public fund in those sectors is poor or not well articulated. It shows that public funds channeled to those sectors impacts a minus on output growth. Most of the funds channeled to these sectors are finding its way out of the economy and depleting the consequential impact on output productivity. The expected of government expenditures on transfer generates the same negative impact on output productivity.

To test our hypothesis we used the probability (p-value) of observing the t-statistic given that the coefficient is equal to zero. In this study we performed the test at the 1,5 and 10 percent significance level, that is, a $p$-value that ranges between $0.01-0.10$ are taken as evidence to reject the null hypothesis of a zero coefficient. The probability values and t-statistics result in Appendix 3, showed clearly that LDODEBT, LGOVREV and LGTEAD are significant for output growth while, LGTESC though positively related but not significant as judged by the $p$-value and t-statistics. Other variable were not significant.

The R-squared statistic measures the success of the regression in predicting the values of the dependent variable within the sample. In standard settings, may be interpreted as the fraction of the variance of the dependent variable explained by the independent variables. R2 show that $98 \%$ of variations in the output growth are accounted for by the changes in the public sector finance management variables, while the F-Stat is 336.57 with a probability of making a type 1 error standing at 0 . With a sufficiently large value for F-Stat and 0 probabilities of errors, it passed the significant test at the $5 \%$ critical level; the critical $F$ value is 2.18 . The result tends to suggest that the overall fit of the regression equation is good. From the result Breusch-Godfry serial correlation LM test, the second order DurbinWatson test stat is 1.89.This indicates that there is weak positive serial correlation after a second order test.

\subsection{Policy implications and recommendation}

This paper has some interesting empirical findings. They are discussed as follows: One, the achievement of sustainable output growth through public sector financial management in Nigeria has a significant role to play in the effort to move the economy in the right direction. This is irrespective of the substantial set back due to unidirectional foreign borrowings, mismanagement of some sectors fund (economic services) and transfers. Two, public sector expenditure when properly channeled has capacity to boost the output growth of the economy. Such public expenditure would have direct impact on the general price level, stimulate income, and aid employment generation in the economy. This finding validates the Keynesian postulation of the need for an active fiscal policy to stimulate 
economic activities. Three, unmitigated leakages of funds in the public sector may have negative consequences on the output growth of the economy. Factors such as frivolous foreign trips, white elephant projects and other acts that lead to fund leakages from the public sector would only serve to negatively impact the implementation of government fiscal policy. Four, to put the Nigerian economy, therefore, along the path of sustainable output growth and development, the government must put a stop to the incessant unproductive foreign borrowing, which may have negative consequences on the economy. When such ventures are not well articulated, the burden of principal and interest payment at point of maturity would have negative impact on the economy. Five, a negative direction of impact on the output growth in the economy is observed from capital and recurrent expenditure on economic services (GTEES). The subsectors in this category include; agriculture, construction, manufacturing, transport \& communication. The impact coefficient of this variable on output growth of the economy shows a negative. This is not expected from such activities. It indicates that these activities are poorly managed. The resources that are committed to the activities of these sectors have been compromised to produce negative results. The activities of the sectors in this category have crucial roles in enhancing the overall growth of the output growth in the economy. All resources committed for expenditure to this sector should be monitored and properly accounted for.

Undoubtedly, the importance of the role of public sector financial management cannot be underemphasized as its effects on the economy cannot be neglected. Hence, to raise output growth in Nigeria, the major areas to seek improvement on the part of the Government based on the findings of this research study would include the following recommendations: One, the Governmental goals on economic advancement should be clear and time lines should be set out for their realization. Government officials must evolve policies that are meant to encourage commitment, probity, accountability and transparency on the part of public fund managers in the execution of public sector projects. Therefore, the budgeting process must be carefully conducted to emphasize key areas that are crucial to the nation's economic advancement. Two, Government should monitor the contract awarding process of capital projects closely by ensuring that due process is followed, to prevent against over estimation of execution cost. This will bring about significant impact of public investment spending (especially on economic activities) on economic growth. The qualifying stage for award of government contracts should ensure that there is competence, experience and professionalism on the part of emerging successful contractors. The effective channeling of public fund to productive activities should have significant and direct impact on economic growth. There should be high degree of transparency and accountability on government spending at various levels and sectors of the economy in order to prevent channeling of public funds to private accounts of government officials. Three, the government monitoring exercise and control function in project execution must be strengthened in the country. Professional project monitoring teams should be commissioned to strengthen the national assembly oversight functions on national projects. Emphasis must be placed on sound financial reporting, professionalism, effective monitoring and good control mechanisms. Four, the culture of leakages, embezzlement of public funds and impunity must be discouraged in the life of public servants in the Country. One of the ways to achieve this is by bringing culprits to book. Where offenders are found to be culpable, they should be made to face the full wrath of the law and committed to jail. There should be not sacred cows in the crusade to rid the public service of corrupt officials. The commitment to jail of corrupt public officers would serve as deterrent to serving public official.

\subsection{Conclusion}

This research study examines the role of public sector financial management on economic growth in Nigeria. Specifically, it critically investigates the role of fiscal measures and its impact on economic output and growth in Nigeria. Empirically, the study reveals that among other things, public sector financial management has positively impacted on output growth of the Nigerian economy. In other words, the null hypothesis that public sector financial management has no significant effect on economic growth in Nigeria should be rejected while the alternative hypothesis that public sector financial management has a significant effect on economic growth in Nigeria should be accepted.

The findings reveal that poor financial management in the public sector and incessant leakages of funds from the system has hampered positive contributions from some key economic sectors of the economy. Therefore the need for proper budget implementation, sound financial discipline and feedback need not be overemphasized. It is worthy to note that proper financial management and practices in the public sector by way of instruments such as government expenditure (capital and recurrent) government borrowings, government revenue such as taxes, tariffs, duties, and other fiscal instruments can still bring about the desired positive change in the economy.

In analyzing the extent of the role of public sector financial management in Nigeria economy and its effects, it discovered that proper public sector financial management plays vital role in economic growth and development of the nation. Productive government expenditure has potential to be growth-enhancing. This finding is consistent with the consensus in existing public sector literature Thus; the study concludes that a clear plan that harmonizes government expenditure with tax revenues and public debts would determine the composition, speed and direction of economic growth. The study therefore, concludes that effective public sector financial management in Nigeria must take into consideration the behavioral pattern and social context of the people. It is evident from this study that the 
main vehicle of executing government plans and actions is the public service, personnel and people. Carefully planned effort to build institutional capacities and personnel for good governance is a pre-requisite to achieve economic advancement and prosperity.

\section{References}

Buchanan, James M., 1986. The constitution of economic policy. American Economic Review, Vol. 77(3): 243-50.

Campos, (Ed) and S. Pradhan, 1996. Budgetary institutions and expenditure outcomes: binding governments to fiscal performance. Policy Research Working Paper 1646. Washington, DC: World Bank.

Central Bank of Nigeria, 2011. Statistical Bulletin, Vol. 22, December, Abuja, Nigeria

Central Bank of Nigeria, 2012. Statistical Bulletin, Vol. 23, December, Abuja, Nigeria

Drucker, Peter, 2001. The essential Drucker: Selections from the management works of Peter F. Drucker. New York: Harper Business.

Easterly, W., 1992. Projection of growth rates outreach 5 Washington, D.C. World Bank Policy Research Dept.

Eisenhardt, K., 1989. Agency theory: an assessment and review, Academy of Management Review, 14 (1): 57-74. http://dx.doi.org/10.5465/AMR.1989.4279003, http://dx.doi.org/10.2307/258191

Ezirim, B. C. \& D. I. M. Ojukwu, 2006. Empirical investigation of the impact of foreign direct investments on the Nigeria economy. Journal of Business Research Vol. 1, No.2, Federal University of Technology Owerri - Nigeria

Fatile, J. O. And K. D. Adejuwon, 2010. Public sector reform in Africa: issues, lessons and future directions. Journal of Sustainable Development in Africa, Vol 12, No.8

Foltin, C., 2005. Finding your way through the government performance maze. Journal of Government Financial Management, Vol. 54 (3): 16-26.

Gujarati, D. N and Sangeetha, 2007. Basic econometrics, Fourth Edition, Tata McGraw-Hill Publishing

Hansen, B. E., 2009. Econometrics, University of Wisconsin

IMF, 2010. Preserving debt sustainability in low-Income countries in the wake of the global crisis, IMF Policy Paper (Washington)

Moynihan, D. and P. Ingraham, 2003. Look for the silver lining: managing for results in state governments. Journal of Public Administration and Theory, 13(4): 469-490. http://dx.doi.org/10.1093/jopart/mug032

Nwezeaku N. C., 2010. The impact of public sector financial management on the economies of sub-Saharan Africa. International Research Journal of Finance and Economics, ISSN 1450-2887, Issue 40.

Obadan, M.I, 2004. Foreign capital flow and external debt perspectives in Nigeria and the LDCs group. Lagos, Broadway Press Limited.

Offurum, C. O., 2005. Impact of public expenditure on economic growth of selected countries. An Unpublished Ph.D Thesis Federal University of Technology, Owerri - Nigeria

Oji, I.O., 2008. Public sector financial management in developing economies, PhD thesis Federal University of Technology Owerri - Nigeria

Ojo, Olu, 2009. Efficient financial management for local governments: The Nigerian experience, Vol. LXI No. 2, BULETINUL Universităţii Petrol - Gaze din Ploiești

Okonjo-Iweala, N., 2006. Government economic reforms: implication for funding education in Nigeria. Nigerian Vanguard Newspaper, March, 23

Olaniyan, Olanrewaju, 2000. The effects of economic instability on aggregate investment in Nigeria. The Nigerian Journal of Economic and Social Studies, Vol. 42(1): 23 - 36.

Olashore, Oladele, 2001. Challenges of Nigeria's economic reform. Ibadan: Fountain Publications, 53(3): 8-9.

Omopariola 0., 2002. 'Nigeria's financial management nightmare.

Onuchukwu, O., 2001. An econometric analysis of government expenditure behavior in Nigeria. Journal of Industrial Business and Economic Research, Vol. 5, No. 2.

Stevens, L.O. and L .M. Freikmann, 2008. Stocktaking the reforms in public financial management. World Bank Report 2008 UNDP Report (1997) Poverty in Sub Saharan Africa.

Tchokote, Joseph, 2001. Macroeconomics of fiscal deficits in Cameroon. A Ph.D. Thesis Proposal presented to the Department of Economics, University of Ibadan, Ibadan - Nigeria. The Bullion, Vol. 27(2): 8-16.

The Association of Chartered Certified Accountants (ACCA), 2010. Improving public sector financial management in developing countries and emerging economies.

United human development Report (2011). http://www.ng.undp.org/

Wildavsky, Aaron., 1986. Budgeting: A Comparative Theory of Budgetary Processes. Revised Edition, New Brunswick, NJ: Transaction Books

World Bank, 2011. World Development indicators

\section{Appendix}

Appendix 01: Unit root test result 
Exogenous variables: Individual effects, individual linear trends

Method: Im, Pesaran and Shin W-stat

Statistic

Prob.**

Im, Pesaran and Shin t-bar

T-bar critical values ***:

$\begin{array}{cccc} & & \text { Statistic } & \text { Prob.** } \\ & & -18.2285 & 0.0000 \\ & & -7.08260 & \\ 1 \% \text { level } & -2.81867 & & \\ 5 \% \text { level } & -2.62567 & & \\ 10 \% \text { level } & -2.52300 & & \end{array}$

** Probabilities are computed assuming asymptotic normality

Intermediate ADF test results

\begin{tabular}{cccccc}
\hline Series & t-Stat & Prob. & $\begin{array}{c}\text { Order of } \\
\text { integration }\end{array}$ & Max Lag & Obs \\
\hline D(LOUTPG) & -9.9350 & 0.0000 & I( 1$)$ & 0 & 41 \\
D(LDODEBT) & -4.6239 & 0.0033 & I( 1$)$ & 0 & 41 \\
D(LEXDEBT) & -5.2285 & 0.0006 & I( 1$)$ & 0 & 41 \\
D(LGOVREV) & -7.0859 & 0.0000 & I( 1$)$ & 0 & 41 \\
D(LGTEAD) & -8.6724 & 0.0000 & I( 1$)$ & 0 & 41 \\
D(LGTEES) & -8.0269 & 0.0000 & I( 1$)$ & 0 & 41 \\
D(LGTESC) & -6.3805 & 0.0000 & I( 1$)$ & 0 & 41 \\
D(LGTTRA) & -7.5737 & 0.0000 & I( 1$)$ & 0 & 41 \\
D(CGOV) & -6.2165 & 0.0000 & I( 1$)$ & 0 & 41 \\
\hline
\end{tabular}

Source: Authors' Computation

Appendix 02: Predictive causality tests result

\begin{tabular}{lccc}
\hline Null Hypothesis: & No. of Lags & F-Statistic & Decision \\
\hline D(LDODEBT) does not Granger Cause D(LOUTPG) & 2 & 2.89517 & Reject \\
D(LOUTPG) does not Granger Cause D(LDODEBT) & 2 & 2.62243 & Reject \\
D(LEXDEBT) does not Granger Cause D(LOUTPG) & 2 & 4.20762 & Reject \\
D(LOUTPG) does not Granger Cause D(LEXDEBT) & 2 & 2.35839 & Reject \\
D(LGOVREV) does not Granger Cause D(LOUTPG) & 2 & 2.07727 & Reject \\
D(LOUTPG) does not Granger Cause D(LGOVREV) & 2 & 0.92020 & Accept \\
D(LGTEAD) does not Granger Cause D(LOUTPG) & 2 & 2.23132 & Reject \\
D(LOUTPG) does not Granger Cause D(LGTEAD) & 2 & 0.78700 & Accept \\
D(LGTEES) does not Granger Cause D(LOUTPG) & 2 & 5.24739 & Reject \\
D(LOUTPG) does not Granger Cause D(LGTEES) & 2 & 0.24637 & Accept \\
D(LGTESC) does not Granger Cause D(LOUTPG) & 2 & 3.77613 & Reject \\
D(LOUTPG) does not Granger Cause D(LGTESC) & 2 & 0.50757 & Accept \\
D(LGTTRA) does not Granger Cause D(LOUTPG) & 2 & 2.19736 & Reject \\
D(LOUTPG) does not Granger Cause D(LGTTRA) & 2 & 0.89893 & Accept \\
D(CGOV) does not Granger Cause D(LOUTPG) & 3 & 0.66005 & Accept \\
D(LOUTPG) does not Granger Cause D(CGOV) & 3 & 1.71640 & Accept \\
\hline
\end{tabular}

Source: Authors' Computation

Appendix 03: Model estimation result

Method: Two-Stage Least Squares

Dependent Variable: D(LOUTPG)

White Heteroskedasticity-Consistent Standard Errors \& Covariance

Instrument list: C D(LOUTPG(-1))D(LGOVREV) D(LGTEAD) D(LGTEES) D(LGTESC) D(LGTTRA) D(CGOV)

Variable

Coefficient

Std. Error

t-Statistic

Prob. 


\begin{tabular}{|c|c|c|c|c|c|}
\hline $\mathrm{C}$ & $\alpha_{0}$ & 1.331358 & 0.591053 & 2.252519 & 0.0311 \\
\hline D(LDODEBT) & $\alpha_{1}$ & 0.701289 & 0.219218 & 3.199051 & 0.0030 \\
\hline $\mathrm{D}($ LEXDEBT $)$ & $\alpha_{2}$ & -0.163894 & 0.100479 & -1.631123 & 0.1124 \\
\hline D(LGOVREV) & $\alpha_{3}$ & 0.597754 & 0.250420 & 2.387008 & 0.0229 \\
\hline D(LGTEAD) & $\alpha_{4}$ & 0.321358 & 0.186511 & 1.722999 & 0.0942 \\
\hline D(LGTEES) & $\alpha_{5}$ & -0.120290 & 0.159687 & -0.753284 & 0.4566 \\
\hline D(LGTESC) & $\alpha_{6}$ & 0.003451 & 0.112152 & 0.030769 & 0.9756 \\
\hline D(LGTTRA) & $\alpha_{7}$ & -0.319208 & 0.389039 & -0.820504 & 0.4178 \\
\hline R-squared & & 0.976197 & Mean dependent var & & 13.16284 \\
\hline Adjusted R-squared & & 0.963269 & S.D. dependent var & & 2.835424 \\
\hline S.E. of regression & & 0.366756 & Sum squared resid & & 4.438821 \\
\hline F-statistic & & 336.5668 & Durbin-Watson stat & & 1.341677 \\
\hline Prob(F-statistic) & & 0.000000 & & & \\
\hline $\begin{array}{l}\text { Durbin-Watson stat (BG, LM } \\
\text { test }\end{array}$ & & 1.887477 & Prob(F-statistic) & & 0.000000 \\
\hline
\end{tabular}

Source: Author's Computation 